\title{
Using A Project/Case Study To Teach Financial Statement Analysis In The Introductory Business Finance Course
}

John T. Rose, (Email: jt_rose@baylor.edu), Baylor University

\begin{abstract}
This study presents a project, written in the form of a case study and accompanied by a Microsoft Excel template, to be assigned to an introductory course in business finance. The objective is to give introductory finance students an application of financial statement analysis beyond that provided by the typical end-of-chapter problems. The project is designed to enable students to link together the information provided by the several analytical tools-common size financial statements, analytical ratios, and the cash flow statement - and so obtain a complete picture of a firm's financial performance over the past several years and relative to the average firm in the industry.
\end{abstract}

\section{INTRODUCTION}

ntroductory finance textbooks must necessarily cover a wide range of topics to give students an overview of the finance discipline and simultaneously prepare finance majors to move on to upper-level finance courses. With most topics, limited coverage (usually, one or two chapters) accompanied by end-of chapter problems is sufficient to give students an adequate introduction to the subject matter. Some topics, however, may be so briefly covered as to generate little substantive understanding, let alone interest, on the part of the student. A good example is "financial statement analysis," which typically follows an overview of the balance sheet and income statement. In a single chapter (or the equivalent thereof presented in multiple sections across two or more chapters) the author may 1) introduce common-size financial statements, 2) present a listing and discussion of the principal analytical financial ratios, including the ratio decomposition provided by the DuPont Identity, and 3) discuss the concept of free cash flow and/or the accounting statement of cash flows. ${ }^{1}$ Such coverage is usually concluded with an array of end-of-chapter problems and questions requiring students to, among other things, calculate and interpret the various analytical ratios, including the DuPont Identity, for a firm. Other problems may focus on free cash flow and/or the accounting statement of cash flows.

Calculating financial ratios, working problems related to a firm's cash flow, and even answering interpretive questions pertaining to calculated data, however, is only the first step in financial statement analysis, which essentially involves "telling a story" about a firm's financial performance over the past few years and relative to other firms in the industry. ${ }^{2}$ And while some of the more challenging end-of-chapter problems do push students

\footnotetext{
${ }^{1}$ See, for example, Block and Hirt [2008], Brealey, Myers, and Marcus [2004\}, Brigham and Houston [2007], Gitman [2006], Keown, Martin, Petty, \& Scott, Jr. [2006], Megginson and Smart [2006], Moyer, McGuigan, and Kretlow [2006], and Ross, Westerfield, \& Jordan [2007]. Of these, Block and Hirt [2008], Brigham and Houston [2007], Gitman [2006], and Megginson and Smart [2006] given attention to both the accounting statement of cash flows and the concept of free cash flow. By contrast, Brealey, Myers, and Marcus [2004] and Moyer, McGuigan, and Kretlow [2006] focus almost entirely on the accounting statement of cash flows and barely mention free cash flow. At the other extreme, Keown, Martin, Petty, and Scott, Jr. [2006] and Ross, Westerfield, and Jordan [2007] merely note the accounting statement of cash flows but spend considerable time on free cash flow or, as labeled in Ross et al., "cash flow from assets."

${ }^{2}$ For an excellent tutorial on the cash flow statement that speaks of the "story" within the statement, see Hertenstein and McKinnon [1997].
} 
to analyze individual areas of firm performance over time or relative to peer-group data, rarely do textbook problems require students to link common-size financial statements, analytical ratios, and cash flow data to tell a complete story about a firm's financial condition. Yet until students learn to tie together the information from the several analytical tools available to the financial analyst, they will never see the breath of information contained in the financial data nor how the information gleaned from one tool is reinforced and illuminated by information provided by other tools.

This study presents a project, written in the form of a case study, which may be assigned in the introductory finance course to give students an appreciation of financial statement analysis beyond that provided by solving the typical end-of-chapter problems. ${ }^{3}$ In so doing, the project/case study is consistent with the new AACSB International's Eligibility Procedures and Standards for Business Accreditation (approved in 2003; revised in 2004 and again in 2005), which mandate in Strategic Management Standard No. 13 that individual teaching faculty members should, among other things, actively involve students in the learning process. ${ }^{4}$ Additionally, the project/case study serves to enhance students' practical skills which Bennis and O'Toole [2005] argue is often sacrificed in business education in favor of a preoccupation with theory and quantitative proficiency. Finally, if assigned to be done by students working in small groups, the project/case study is consistent with another requirement of AACSB Standard No. 13, namely, that faculty members should encourage collaboration and cooperation among students, as well as Standard No. 14, which requires that individual students should, among other things, contribute to the learning of others. ${ }^{5}$

Of course, assigning such a collaborative project introduces the "free rider" issue, namely, the possibility that the weaker students may simply let the stronger students do most, if not all, of the work. To deal with this issue, the instructor may ask students to complete a "colleague evaluation" of the contribution of each of their group members, which can be factored into the project grade for students identified by their group members as making little or no contribution to the project solution. Such an evaluation requirement not only encourages students to participate fully with their group, but it also gives them experience in personnel performance evaluation which many of them will someday be required to do as part of their professional managerial responsibilities. Alternatively, the instructor may give an exam on the project after it is completed, or include some project-related questions on the next general exam, in order to provide an incentive for all students to contribute to the project solution.

The project outlined below is set in the case context of a student who has been offered employment with a hypothetical firm and wishes to determine if the firm is in sound financial condition before deciding whether to accept the job. ${ }^{6}$ Thus, the project requires students to use financial statements of the firm, plus a Microsoft Excel template provided by the instructor, to 1) construct common-size financial statements, 2) calculate financial ratios, 3) prepare cash flow statements, and 4) answer a series of analytical questions addressing the firm's financial performance in the areas of liquidity, solvency, asset management, profitability, and cash flow, as well as the market's assessment of the firm's financial condition. In addition, students may be asked to obtain industry data

\footnotetext{
${ }^{3}$ As originally designed, this project required that students link only common-size financial statements and financial ratios. I am grateful to my colleague Ernest Fletcher, who suggested that the linkage be extended to include the cash flow statement. In fact, this the second of two projects developed by the author to be assigned in the introductory finance course. The first project- $\mathrm{a}$ hypothetical capital budgeting project - is presented in the context of a case study in Rose and Delaney [2005] and again in a different case scenario in Coldwell and Rose [2006].

${ }^{4}$ Projects, like case studies, represent an important pedagogical tool to involve students actively in the learning process. For a discussion of active learning (sometimes termed "student-centered") techniques in teaching finance, see Moore [1999] and the literature cited. Additionally, Bruner, Gup, Nunnally, Jr., and Petit [1999] reviewed the literature of the previous twenty-five years on the relevant issues in incorporating case studies in finance instruction. More recently, Nunnally and Evans [2003] discuss the benefits of using integrative cases in the introductory finance course to help students understand the linkages between finance and the other business disciplines, and Yobaccio, Kennedy, and Schumacher [2006] present a student-centered program to integrate statistics and introductory finance.

${ }_{6}^{5}$ For a recent discussion of the merits of team/group learning in introductory finance classes, see Ingram and Adams [2003].

${ }^{6}$ Clearly, this case context is not necessary to analyze the firm's financial performance. The objective of such a context is to draw students into the project as a more practical and interesting assignment than an end-of-chapter problem. In addition, perhaps it will encourage students to use their knowledge of financial statement analysis to analyze a firm's financial condition before interviewing with the firm and certainly before accepting employment with the firm.
} 
from Annual Statement Studies: Financial Ratio Benchmarks published by RMA-The Risk Management Association (formerly known as The Robert Morris Associates), or, with RMA's permission, the instructor may include a copy of the appropriate RMA industry data with the project assignment. The series of analytical questions is designed to enable students to link together the information provided by the several analytical tools and so obtain a complete picture of the firm's financial performance over the past several years and relative to the average firm in the industry.

The choice to use a hypothetical firm, rather than a real firm, reflects the fact that with a hypothetical firm the instructor can construct financial statement information to highlight particular financial strengths and weaknesses of the firm, which is especially useful in teaching introductory students. Also, by using a hypothetical firm the instructor precludes students from circumventing the analytical process by finding external performance reviews, as they might be able to do with a real firm.

In the next section a sample project, written in the form of a case study, is presented as it might be assigned to students. Teaching notes, including the spreadsheet solution to the project and answers to the several analytical questions are available from the author upon request.

\section{A SAMPLE PROJECT}

Case Setting: It is Spring 2006 and you are looking for full-time employment. Plush Carpet Mill, Inc. (PCM) has offered you a position as manager of its San Antonio, Texas production facility. Before accepting the job, however, you want to evaluate PCM's financial performance to make sure it is a sound company.

PCM has provided you a copy of its year-end 2003, 2004, and 2005 balance sheets and income statements (Exhibit 1), and you plan to obtain industry data from the 2004-2005 edition of Annual Statement Studies: Financial Ratio Benchmarks prepared by RMA-The Risk Management Association. Your task now is to assess the financial condition of PCM through both 1) a 2003-05 trend (historical) analysis and 2) a 2005 peer group (industry) analysis using 2005 data for PCM and RMA data for the carpet mill industry. Remember: In doing your analysis you are essentially telling a story about PCM's financial performance over the last few years and relative to other similarsized firms in the industry.

Required: This assignment involves a Microsoft Excel template provided by your instructor (Exhibit 2) with four major components. First, you must enter data from the financial statements of PCM into the Excel spreadsheet (every cell containing an "A"), either by entering the data directly or by entering an appropriate cellreferenced equation, for the three years 2003-05. ${ }^{7}$ Second, you must enter cell-referenced equations into the template to construct 1) common-size balance sheets and income statements for each of the three years (every cell containing a "B"), 2) financial ratios for each of the three years (every cell containing a "C"), and 3) accounting cash flow statements for 2004 and 2005 (every cell containing a "D"). For simplicity, all financial ratios requiring balance sheet data should be calculated using year-end figures rather than an average of beginning-of-year and endof-year data. Next, you must enter 2003/04 industry data (common-size financial statement data and financial ratios) for "Manufacturing - Carpet and Rug Mills (NAICS 314110, SIC 2273)" from the 2004-2005 edition of RMA’s Annual Statement Studies: Financial Ratio Benchmarks (every cell containing an "E"). Limit your industry analysis to RMA data collected from firms with sales of " $25 \mathrm{MM} \&$ Over" to compare with 2005 data for PCM. Finally, you must assign qualitative assessments of Good, OK/Good, OK, OK/Poor, or Poor to the trends in each of

\footnotetext{
${ }^{7}$ Using summation/subtraction equations, along with reconciling equations for depreciation expense/accumulated depreciation and additions to retained earnings/accumulated retained earnings, will ensure that the financial statements are arithmetically correct and appropriately reconciled. In that regard, the instructor may "plant" one or more incorrect figures in the financial statements provided to the students in order to impress upon students the importance of checking the arithmetic and reconciliation of the balance sheet and income statement prior to calculating any ratios or constructing a statement of cash flows.

${ }^{8}$ Because the RMA data presents industry financial ratios for the first, second (median), and third quartiles, students should use the median number as the average (or industry) ratio for purposes of their analysis. Students should understand that they will likely not have industry data corresponding to every item of firm data. Moreover, they will probably have some industry data with no corresponding firm data. Such inconsistencies are simply a fact of life in financial statement analysis.
} 
the firm's financial ratios as well as to the degree to which the firm's financial ratios are superior to the matching industry ratios (every cell containing an "F").

In addition to the Excel requirements outlined above, you must answer the following set of analytical questions on the several areas of financial performance - liquidity, asset management, financing of assets, profitability, and cash flow-and then pull all of your analysis together to give an overall evaluation of the firm. In answering these questions, do not forget to look at the firm's common-size balance sheet and income statement items, including trends over 2003-05 and the relationship of 2005 common-size ratios to industry data. Oftentimes, you will see patterns in the common-size ratios that reinforce and further explain patterns in the financial ratios, and vice versa. Finally, you must consider the market's assessment of the firm and, based on both yours and the market's assessment, decide whether you would accept employment with the firm.

\section{LIQUIDITY}

1. Look at the current ratio and the quick (acid-test) ratio of PCM. What trends do you notice over 2003-05, and what does this suggest about PCM's liquidity? How does PCM's liquidity in 2005 compare with the industry average?

2. Now study the accounts receivables turnover and inventory turnover of PCM. What do these patterns suggest about the firm's conversion of accounts receivable and inventories to cash?

3. Considering your answers to the two questions above, what is your overall assessment of PCM's liquidity position? What two major factors account for your assessment?

\section{ASSET MANAGEMENT}

4. What is your assessment of the manner in which PCM is managing its assets? Pay attention to both trends and industry averages.

\section{FINANCING OF ASSETS}

5. What is your assessment of the manner in which PCM is financing its assets? Pay attention to both trends and industry averages. What is the relationship between the total debt ratio and times interest earned as these relate to PCM? And is there any other possible explanation (outside of the firm's financial statements) for the observed trend in times interest earned?

\section{PROFITABILITY}

6. What can you say about PCM's operating profit margin and pre-tax net profit margin? ${ }^{9}$ Explain any patterns observed.

7. How are PCM's pre-tax net profit margin, total asset turnover, and total debt ratio affecting the firm's pretax return on assets (ROA) and return on equity (ROE)? What is your overall assessment of the firm's profitability, including its earnings per share (EPS)?

\section{CASH FLOW}

8. Referring to PCM's statement of cash flow for 2004 and 2005, assess PCM's cash flow situation noting both inflows and outflows?

\footnotetext{
${ }^{9}$ The focus on pre-tax profitability measures (net profit margin, ROA, and ROE) in Questions 6 and 7 reflects the fact that the RMA Annual Statement Studies presents only pre-tax profitability data for each industry.
} 


\section{OVERALL EVALUATION}

9. Based on your answers to the questions above, what is your overall evaluation of PCM's financial condition? (Pull all your analysis together in answering this question.)

10. What is the market's assessment of PCM's financial condition? Explain. Does the market's assessment confirm or refute your analysis?

11. Based on your evaluation of PCM and the market's assessment of the firm, would you accept employment with the company? Explain.

\section{TEACHING NOTES}

Teaching notes available from author.

\section{REFERENCES}

1. Bennis, W. G. and J. O’Toole. How Business Schools Lost Their Way, Harvard Business Review, 83 (May 2005), 96-104.

2. Block, S. B. and G. A. Hirt. Foundations of Financial Management, $12^{\text {th }}$ ed. New York, NY: McGrawHill/Irwin, 2008.

3. $\quad$ Brealey, R. A., S. C. Myers, and A. J. Marcus. Fundamentals of Corporate Finance, $4^{\text {th }}$ ed. New York, NY: McGraw-Hill/Irwin, 2004.

4. Brigham, E. F. and J. F. Houston. Fundamentals of Financial Management, $11^{\text {th }}$ ed. Mason, OH: Thomson South-Western, 2007

5. $\quad$ Bruner, R. F., B .E. Gup, B. H. Nunnally, Jr., and L. C. Pettit. Teaching with Cases to Graduate and Undergraduate Students, Financial Practice and Education, 9 (Fall/Winter 1999), 138-146.

6. Coldwell, C. L. and J. T. Rose. Teaching and Application in Introductory Finance: Using an Excel-based Case Study as a Pedagogical Tool, Journal of Business Case Studies, 2 (First Quarter 2006), 23-27.

7. Gitman, L. J. Principles of Managerial Finance, $11^{\text {th }}$ ed. Boston, MA: Pearson Addison Wesley, 2006.

8. Hertenstein, J. H. and S. M. McKinnon. Solving the Puzzle of the Cash Flow Statement, Business Horizons, January/February 1997, 69-76.

9. Hruby, G., D. Kahl, and M. Newman. Integrating Real-World Experience with the Classroom Experience: Two Different Approaches, Advances in Financial Education, 1 (Fall 2003), 28-40.

10. Ingram, V. and J. S. Adams. Effects of Team Learning on Success Rates in Introductory Finance Classes, Journal of Financial Education, 29 (Fall 2003), 28-39.

11. Keown, A. J., J. D. Martin, J. W. Petty, and D. F. Scott, Jr. Foundations of Finance, $5^{\text {th }}$ ed. Upper Saddle Rich, NJ: Prentice Hall, 2006.

12. Megginson, W. L. and S. B. Smart. Introduction to Corporate Finance. Mason, OH: Thomson SouthWestern, 2006.

13. Moore, S. Cases vs. Lectures: A Comparison of Learning Outcomes in Undergraduate Principles of Finance, Journal of Financial Education, 25 (Fall 1999), 37-49.

14. Moyer, R. C., J. R. McGuigan, and W. J. Kretlow. Contemporary Financial Management, $10^{\text {th }}$ ed. Mason, OH: Thomson South-Western, 2006.

15. Nunnally, B. H. Jr. and M. D. Evans, Case Teaching and the Integrative Process, Journal of Financial Education, 29 (Spring 2003), 75-86.

16. Rich, S. P. The Real-Time Restructuring Project: Maximizing Student Learning with Minimal Professor Effort, Journal of Financial Education, 31 (Winter 2005), 64-75.

17. Rose, J. T. and C. J. Delaney. Meeting the Mandate(s): Using a Project/Case Study to Comply with the New AACSB Accreditation Standards, Journal of Financial Education, 31 (Summer 2005), 89-98.

18. Ross, S. A., R. W. Westerfield, and D. D. Jordan. Essentials of Corporate Finance, $5^{\text {th }}$ ed. New York, NY: McGraw-Hill, 2007.

19. Yobaccio, E. J., K. Kennedy, and P. Schumacher. A Multidisciplinary and Student-Centered Approach to Teaching Quantitatively in Introductory Finance, Advances in Financial Education, 4 (Spring 2006), 1-13. 
Exhibit 1

Plush Carpet Mill, Inc.

Balance Sheets (\$000)

\begin{tabular}{|c|c|c|c|}
\hline & \multicolumn{3}{|c|}{ December 31} \\
\hline & 2003 & 2004 & 2005 \\
\hline \multicolumn{4}{|l|}{ Assets } \\
\hline \multicolumn{4}{|l|}{ Current assets } \\
\hline Cash & 1,512 & 1,176 & 1,097 \\
\hline Accounts receivable & 6,237 & 10,271 & 15,919 \\
\hline Inventories & 4,536 & 7,838 & 12,570 \\
\hline Prepaid expenses & 3,780 & 5,140 & 6,840 \\
\hline Total current assets & $\overline{16,065}$ & $\overline{24,425}$ & $\overline{36,426}$ \\
\hline Gross fixed assets & 6,300 & 9,080 & 12,918 \\
\hline Less: Accumulated depreciation & 2,050 & 2,958 & 4,250 \\
\hline Net fixed assets & $\overline{4,250}$ & $\overline{6,122}$ & $\overline{8,668}$ \\
\hline Intangible assets & 567 & 588 & 605 \\
\hline All other noncurrent assets & 1,323 & 1,790 & 1,985 \\
\hline Total Assets & $\underline{\underline{22,205}}$ & $\underline{\underline{32,925}}$ & $\overline{47,684}$ \\
\hline \multicolumn{4}{|l|}{ Liabilities and Stockholders Equity } \\
\hline \multicolumn{4}{|l|}{ Current liabilities } \\
\hline Notes payable & 1,205 & 3,243 & 6,323 \\
\hline Current maturities--L.T.D. & 1,008 & 1,460 & 2,246 \\
\hline Accounts payable & 3,570 & 5,958 & 9,955 \\
\hline Income taxes payable & 84 & 336 & 336 \\
\hline Accruals & 1,995 & 3,360 & 5,016 \\
\hline Total current liabilities & $\overline{7,862}$ & $\overline{14,357}$ & 23,876 \\
\hline Long-term debt & 2,940 & 6,100 & 9,350 \\
\hline Total Liabilities & $\overline{10,802}$ & $\overline{20,457}$ & $\overline{33,226}$ \\
\hline \multicolumn{4}{|l|}{ Stockholder's equity } \\
\hline Common stock ${ }^{10}$ & 3,360 & 3,360 & 3,360 \\
\hline Paid-in capital & 2,100 & 2,100 & 2,100 \\
\hline Retained earnings & 5,943 & 7,008 & 8998 \\
\hline Total stockholders' equity & $\overline{11,403}$ & $\underline{12,468}$ & $\overline{14,458}$ \\
\hline Total liabilities \& equity & $\underline{\underline{22,205}}$ & $\underline{\underline{32,925}}$ & $\overline{47,684}$ \\
\hline Market price per common share & 17.25 & 17.71 & 18.43 \\
\hline
\end{tabular}

Plush Carpet Mill, Inc. Income Statements $\mathbf{( \$ 0 0 0 )}$

\begin{tabular}{|c|c|c|c|}
\hline & 2003 & 2004 & 2005 \\
\hline Sales revenue & 50,400 & 65,100 & 81,312 \\
\hline Less: Cost of goods sold & 35,431 & 45,872 & $\underline{57,098}$ \\
\hline Gross profit & $\overline{14,969}$ & $\overline{19,228}$ & 24,214 \\
\hline \multicolumn{4}{|l|}{ Less: Operating expenses } \\
\hline Gen. \& Adm. and Selling & 12,331 & 15,099 & 17,296 \\
\hline Depreciation & 630 & 908 & 1,292 \\
\hline Total operating expense & $\overline{12,961}$ & $\overline{16,007}$ & $\underline{18,588}$ \\
\hline Operating income (EBIT) & 2,008 & 3,221 & 5,626 \\
\hline Less: Interest expense & 335 & 756 & 1,343 \\
\hline Earnings before taxes (EBT) & $\overline{1,673}$ & $\overline{2,465}$ & 4,283 \\
\hline Less: Income taxes $(34 \%)$ & 569 & 838 & $\underline{1,456}$ \\
\hline Net income & $\overline{1,104}$ & $\overline{1,627}$ & 2,827 \\
\hline Dividends paid & 314 & 562 & 837 \\
\hline
\end{tabular}

${ }^{10} 2,000,000$ shares authorized at $\$ 3$ par. Number of shares issued and outstanding in 2003-05: 1,120,000. 
Exhibit 2

Financial Statement Analysis Project Template

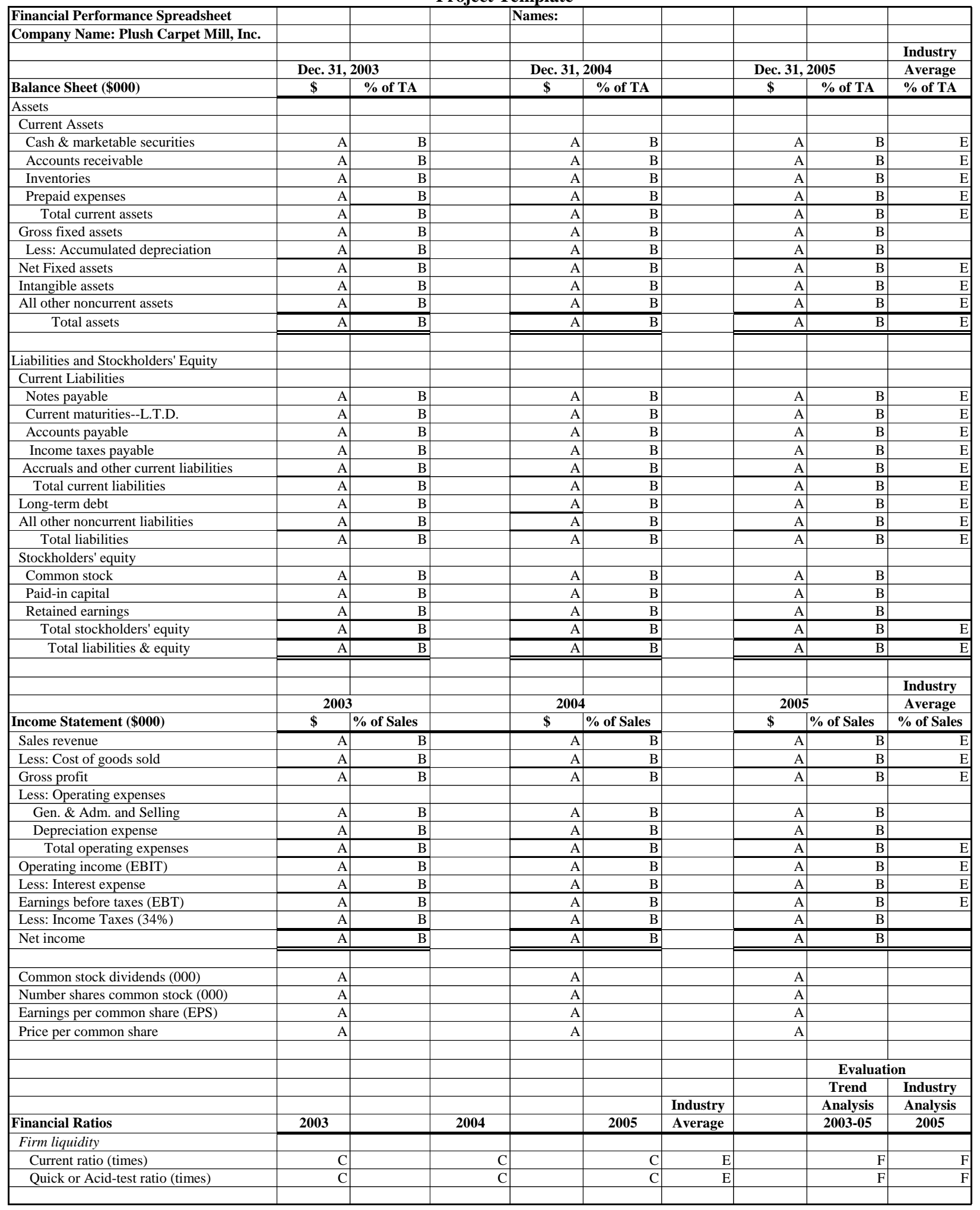


Exhibit 2 (continued)

Financial Statement Analysis

Project Template

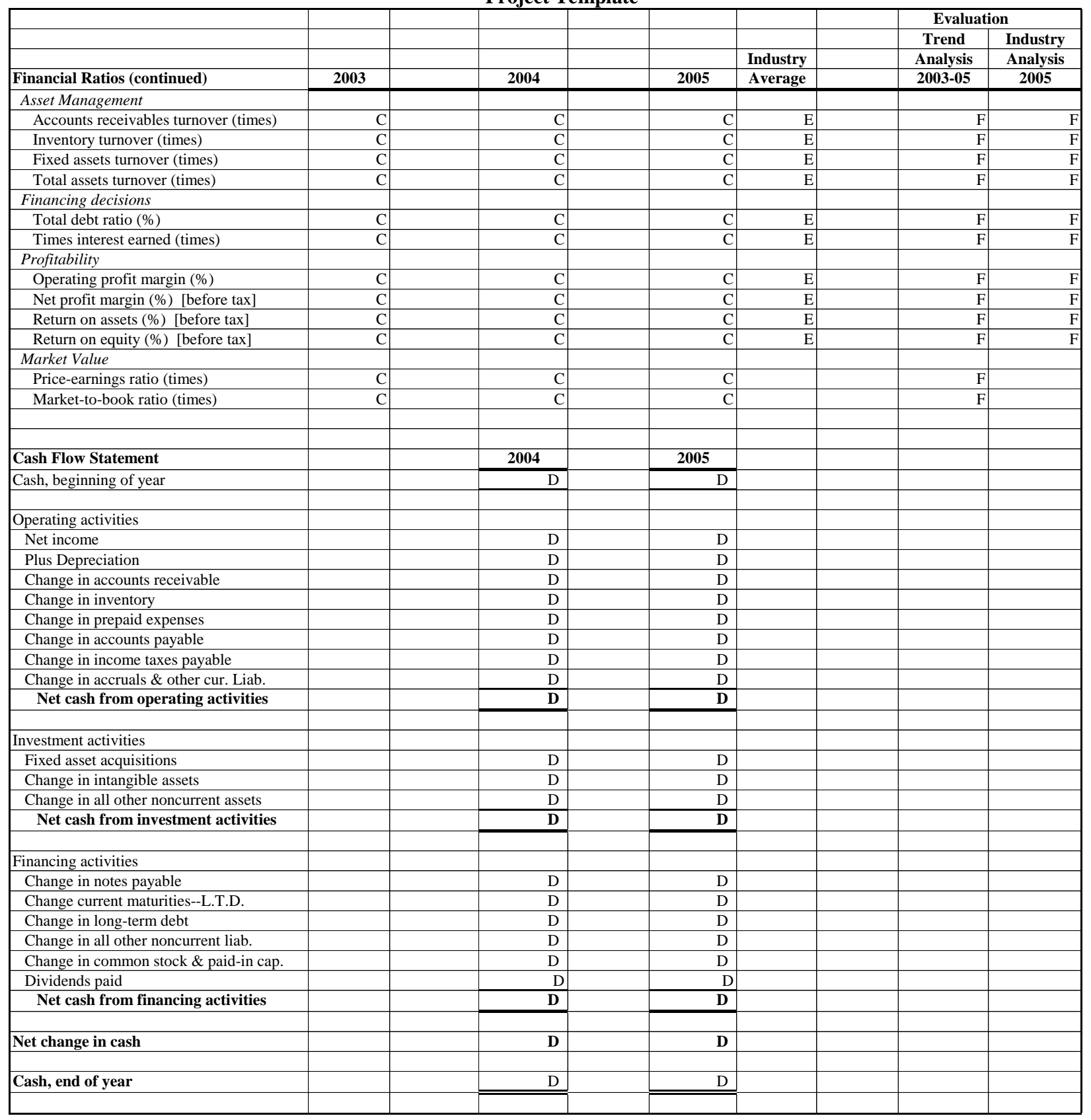

